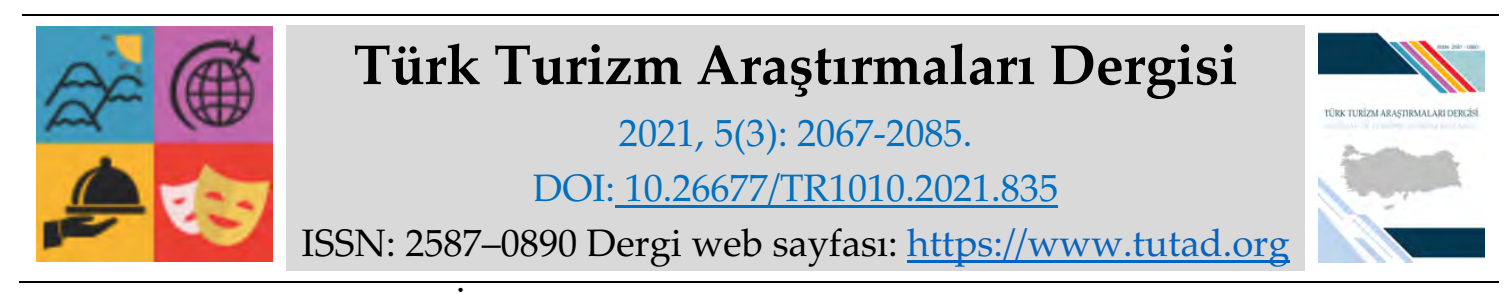

ARAŞTIRMA MAKALESI

\title{
Hizmet Kalitesi ve Müşteri Tatmininin Tekrar Satın Alma Niyetine Etkisi: Z Kuşağ1 Kahve Dükkânı Müşterileri Üzerine Bir Araştırma*
}

Dr. Öğr. Üyesi Bilge ÇAVUŞGIL KÖSE, Çanakkale Onsekiz Mart Üniversitesi, Ezine Meslek Yüksekokulu, Çanakkale, e-posta: bilgecavusgilkose@comu.edu.tr

ORCID: https://orcid.org/0000-0001-8646-4401

Doç. Dr. Sena ERDEN AYHÜN, Çanakkale Onsekiz Mart Üniversitesi, Çanakkale Sosyal Bilimler Meslek Yüksekokulu, Çanakkale, e-posta: senaerden@comu.edu.tr

ORCID: https://orcid.org/0000-0003-0142-1344

\section{Öz}

Son yıllarda hem dünyada hem de ülkemizde kahve işletmeleri popüler tüketim kültürünün odağı haline gelmektedir. Bu işletmeler sundukları hızlı ilişki ve uygun fiyatlar ile çoğunlukla "genç " tüketici grubu tarafından tercih edilmektedirler. Söz konusu bu genç tüketici grubu pazarlama ve tüketici davranışı açısından güncel araştırma konuları arasında yer almakta ve $Z$ kuşağı tüketiciler olarak adlandırılmaktadır. Araştırmanın amacı $Z$ kuşağı bireylerde hizmet kalitesi ve müşteri tatmininin tekrar satın alma niyetine etkilerini incelemektir. Araştırmanın amacı doğrultusunda Çanakkale kent merkezinde yer alan iki adet Starbucks kahve dükkanından ürün satın alan $621 \mathrm{Z}$ kuşağı tüketiciye anket uygulanmıştır. Anketlerden elde edilen veriler SmartPLS 3.3.3. istatistik paket programı kullanılarak analiz edilmiştir. Araştırma sonucunda hizmet kalitesinin müşteri tatminini ve tekrar satın alma niyetini olumlu yönde etkilediği ortaya çımıştır. Benzer biçimde müşteri tatmininin de tekrar satın alma niyetini olumlu yönde etkilediği ve hizmet kalitesi ile tekrar satın alma niyetini arasındaki ilişkide aracılık rolü oynadığı saptanmıştır.

* Bu makale, 27-28 Kasım 2020 tarihleri arasında düzenlenen 1. Örgütlerin Yönetimi Uluslararas1 Kongresi'nde sözlü olarak sunulan Hizmet Kalitesi ve Müşteri Tatmininin Tekrar Satın Alma Niyetine Etkisi: Z Kuşă̆ı Kahve Tüketicileri Üzerine Bir Araştırma isimli bildirinin genişletilmiş halidir.

Anahtar Kelimeler: Hizmet Kalitesi, Müşteri Tatmini, Tekrar Satın Alma Niyeti, Kahve İşletmesi, Z Kuşağı. Makale Gönderme Tarihi: 04.06.2021

Makale Kabul Tarihi: 02.09.2021

\footnotetext{
Önerilen Atıf:

Çavuşgil Köse, B. ve Erden Ayhün, S. (2021). Hizmet Kalitesi ve Müşteri Tatmininin Tekrar Satın Alma Niyetine Etkisi: Z Kuşağı Kahve Dükkânı Müşterileri Üzerine Bir Araştırma, Türk Turizm Araştırmaları Dergisi, 5(3): 2067-2085.

(C) 2021 Türk Turizm Araştırmaları Dergisi.
} 


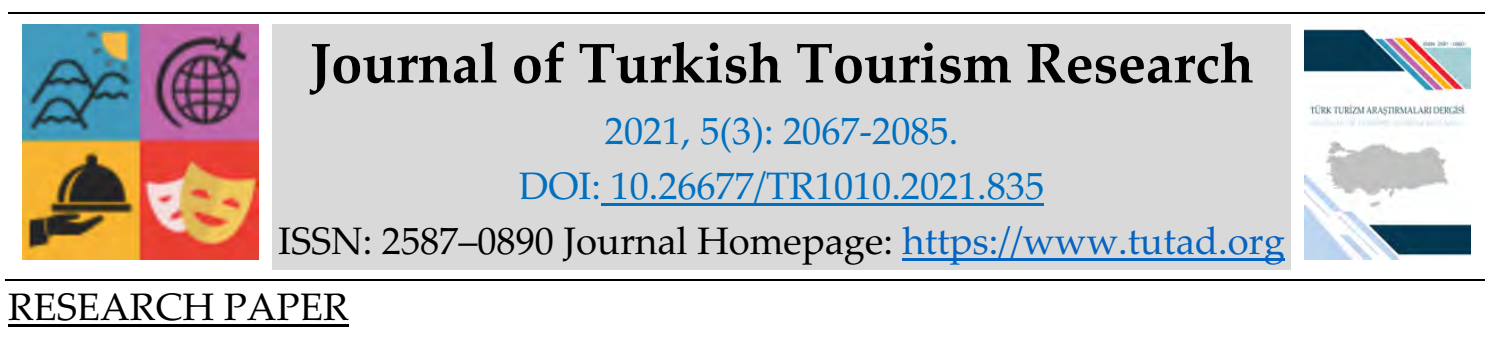

\title{
The Effect of Service Quality and Customer Satisfaction on Repurchase Intention: A Study on Generation Z Coffee Shop Customers
}

Assistant Prof. Dr. Bilge ÇAVUŞGİL KÖSE, Çanakkale Onsekiz Mart University, Ezine Vocational School, Çanakkale, e-mail: bilgecavusgilkose@comu.edu.tr

ORCID: https://orcid.org/0000-0001-8646-4401

Associate Prof. Dr. Sena ERDEN AYHÜN, Çanakkale Onsekiz Mart University, Çanakkale Vocational School of Social Sciences, Çanakkale, e-mail: senaerden@comu.edu.tr

ORCID: https://orcid.org/0000-0003-0142-1344

\begin{abstract}
In recent years, coffee businesses have become the focus of popular consumption culture both in the world and in our country. These businesses are mostly preferred by the "young" consumer group with their fast relations and affordable prices. This young consumer group is called Generation $\mathrm{Z}$ consumers and among the current research topics in terms of marketing and consumer behavior. The study aims to examine the effects of service quality and customer satisfaction on repurchase intention in Generation $\mathrm{Z}$ individuals. In line with this purpose, a questionnaire was applied to 621 Generation $Z$ consumers who purchased products from two Starbucks coffee shops in Çanakkale city center. Data from surveys were analyzed by SmartPLS 3.3.3. statistical package program. As a result of the research, it was revealed that service quality positively affected customer satisfaction and repurchase intention. Similarly, it has been determined that customer satisfaction positively affects repurchase intention and plays a mediating role in the relationship between service quality and repurchase intention.
\end{abstract}

Keywords: Service Quality, Customer Satisfaction, Repurchase Intention, Coffee Business, Generation Z.

Received: 04.06.2021

Accepted: 02.09.2021

\section{Suggested Citation:}

Çavuşgil Köse, B. and Erden Ayhün, S. (2021). The Effect of Service Quality and Customer Satisfaction on Repurchase Intention: A Study on Generation Z Coffee Shop Customers, Journal of Turkish Tourism Research, 5(3): 2067-2085.

(C) 2021 Türk Turizm Araştırmaları Dergisi. 


\section{Gíriş}

Bugünün dünyasında işletmeler kalıcı müşteri kitlesi oluşturarak müşteri tatmini yaratmayı ve sürdürülebilir kar elde etmeyi amaçlamaktadırlar. Özellikle markalaşma sürecini başarıyla tamamlayan pek çok işletme incelendiğinde hizmet kalitesi ve müşteri tatminine özen gösterdikleri dikkatlerden kaçmayan bir unsur olmaktadır. Buna ilaveten işletmeler yeni müşteriler elde edebilmelerinin yanında mevcut müşterilerinin tekrar satın alma davranışlarında bulunmalarını da arzulamaktadırlar. Bu kapsamda müşteri bağlılığ yaratarak, söz konusu müşterilerin tekrar satın alma davranışlarına yönelmesi amaçlanmaktadır. Başka bir ifadeyle günümüzün rekabetçi süreçleri işletmeleri sadık müşteri grubu oluşturmaya yönelik stratejiler üretmeye yönlendirmektedir. Bu doğrultuda işletmeler, demografik ve sosyolojik temelleri ile tüketiciyi anlamada 1şık tutan kuşak kavramından ve kuşaklar arasında var olan tüketim farkliliklarından yararlanabilmektedirler.

Kuşak teorisi; doğum yılları itibariyle benzer politik ve sosyal olayları yaşayan, eşsiz değer yargıları ve inanç sistemlerini bünyelerinde geliştiren, birbirine benzer kişilik özellikleri gösteren bireylerden oluşan bir topluluğu ileri sürmektedir (Erden Ayhün, 2013: 96). Kuşak teorisyenleri tarafından yapılmış pek çok çalışma kuşak gruplarını; gelenekçi kuşak, sessiz kuşak, bebek patlaması kuşağı, X kuşağı, Y kuşağı ve Z kuşağı olarak sınırlandırmaktadır (Güzel, 2018: 1). Disiplinler arası bir kavram olarak kuşak teorileri; kuşak üyelerinin davranış biçimleri ve tüketim alışkanlıklarını değerlendirme olanağı vermesi nedeniyle dinamik yapısıyla pazarlama faaliyetlerinin sıkça güncellenmesini gerektiren turizm endüstrisi açısından büyük önem arz etmektedir. Şüphesiz, turizm endüstrinin önemli bir kolu olan yiyecek-içecek işletmeleri de kuşak teorilerinin sunduğu bu faydadan yararlanmalıdır.

Tıpkı fast food tarzı restoranlar gibi sundukları hızlı ilişki ve uygun fiyatlar ile kahve işletmeleri çoğunlukla "genç " tüketici grubu tarafından tercih edilmektedirler. Yiyecek-içecek sektörünün yükselen yıldızı olan kahve işletmelerine her geçen gün bu konsept dahilinde hizmet sunan pek çok yeni işletme eklenmektedir. Nguyen (2020) kahve sektörü için gelecek vaat eden bir müşteri grubu olarak özellikle Z kuşağının önemli bir rol oynadığını belirtmektedir. Söz konusu bu bilgiler 1şığında çalışmada günümüzün ve geleceğin müşterilerini ihtiva etmesi nedeniyle $Z$ kuşağına yönelik bir araştırma yapılması tercih edilmiştir. Bu doğrultuda, araştırmada özellikle gençler tarafından tercih edilen ve yiyecek-içecek sektöründe bir dünya markası olan Starbucks kahve zinciri (Bezirgan vd., 2019: 742) işletmesinden hizmet alan $\mathrm{Z}$ kuşağı müşteriler hedef alınmıştır. Çalışmada işletmelerin karlılıklarını artırmalarında ve sürdürülebilir kılmada önem verdikleri bir müşteri grubu olan $\mathrm{Z}$ kuşağının hizmet kalitesi ve müşteri tatmin düzeylerinin tekrar satın alma niyetlerine olan etkisi belirlenmeye çalışılmıştır.

\section{KAVRAMSAL ÇERÇEVE}

\section{Hizmet Kalitesi}

En basit ifadeyle kalite kavramı, mal veya hizmetin müşteri gereksinim ve beklentilerini karşılayabilme yeteneği olarak açılanmaktadır (Zengin ve Erdal, 2000: 45). Hizmet kalitesi ise; müşteri beklentileri ile algılamaları arasındaki farklılıklar olarak ifade edilmektedir (Parasuraman vd., 1985: 42). Hizmet kalitesi, rekabet avantajı sağlayabilen ve örgütsel karlılığ1 artıran önemli bir stratejik değişken olarak görülmektedir (Ioannou ve Melanthiou, 2015: 2).

Hizmet kalitesinin ölçülmesi işletmelerin piyasadaki konumunun değerlendirilmesini sağlayarak, işletmelerin rekabetçi olabilmesinde stratejik bir avantaj sağlamaktadır. Müşteriler tarafından algılanan hizmet kalitesinin özellikleri sayesinde işletmeler güçlü ve zayıf yönleri ile 
karşılarına çıkabilecek fırsatları değerlendirerek söz konusu alanlara odaklanmakta ve kendilerini geliştirmektedirler (Khan, 2010: 165). Ayrıca, hizmet kalitesi süreçlerinin müşterilerin hizmet deneyimi algılarında güçlü etkiler yaratacağ belirtilmektedir (Kim ve Moon, 2009: 144). Bu bağlamda alan yazınında; hizmet kalitesi alt boyutlarını oluşturan servis ve fiziksel çevre kalitesinin müşteri tatminine olumlu yönde etkisi olduğu belirlenmiştir (Kement, 2019: 1252). Buna ilaveten hizmet kalitesi ve müşteri tatmini, tüketicilerin hizmet ortamlarında satın alma niyetlerinin oluşumunda önemli etkileri olarak kabul edilmektedirler (Taylor ve Baker, 1994: 163). Farklı çalışmalarda hizmet kalitesinin algılanan değeri ve müşteri tatminini olumlu yönde etkileyeceği, müşteri tatmininin satın alma sonrasındaki niyeti olumlu yönde etkileyeceği ve hizmet kalitesinin de müşteri tatmini veya algılanan değer yoluyla satın alma sonrası niyet üzerinde dolaylı pozitif etkisinin olacağı belirtilmektedir (Kuo vd., 2009: 887). Vanniarajan ve Gurunathan (2009: 108); hizmet kalitesi ile tekrar satın alma niyeti arasında müşteri memnuniyetinin aracılık rolünün olduğunu belirlemiştir.

Wall ve Berry (2007: 59) restoran işletmelerinde müşterinin belirli bir işletmeyi değerlendirmesinde yemek kalitesinin temel olmakla birlikte ambiyans ve servis performansının büyük ölçüde etkisinin bulunduğunu eklemektedirler. Bu doğrultuda restoran işletmelerinde hizmet kalitesinin en az bu üç katmandan oluşan bir deneyim olduğunu ifade etmektedirler. Benzer biçimde, Ryu ve Han (2010: 311) çalışmalarında restoran endüstrisindeki toplam yemek hizmetinin, hem somut (gıda ve fiziksel tesisler) hem de soyut (çalışan-müşteri etkileşimi) bileşenleri kapsadığını belirmektedirler. Yazarlar, restoran işletmelerinde hizmet kalitesinin yiyecek ve içecek kalitesi, fiziksel çevre kalitesi ve servis kalitesi boyutları ile değerlendirilmesi gerektiğini, ancak müşterilerin restoran hizmet kalitesi algısı üzerindeki bu üç etkinin ayrı ayrı etkileri üzerine daha önce bazı çalışmalar yapılmış olsa da bunların bir arada ele alındığı hiçbir çalışma bulunmadığını vurgulamaktadırlar. Kement (2019) üçüncü nesil kahve sunan işletmelerde hizmet kalitesi, tatmin ve davranışsal niyetleri incelediği çalışmasında da bu işletmelerde sunulan kahve hizmetinin kalitesini; yiyecek içecek kalitesi, servis kalitesi ve fiziksel çevre kalitesi olmak üzere üç alt boyutta ele almıştır. Bu bilgiler ışığında bu araştırmada hizmet kalitesi yiyecek-içecek kalitesi, etkileşim(servis) kalitesi ve fiziksel çevre kalitesi olmak üzere üç alt boyutta ele alınmıştır.

Yiyecek-İçecek Kalitesi: Yiyecek içecek kalitesi, yiyecek içecek endüstrisinde önemli rol oynamaktadır. Gıdanın taze, lezzetli, besleyici olması, farklı menüler sunması ve müşteriye hitap edebilmesi yiyecek içecek kalitesinin bileşenlerini oluşturmaktadır. Müşteriler, yiyecek içecek kalitesine göre ekstra ödemeye hazırdırlar. Yiyecek içecek kalitesi müşteri tatminini de etkileyen bir unsurdur. Yazında yapılan araştırmalar hizmet kalitesi ve yiyecek içecek kalitesinin müşteri tatminini etkilediğini ve tekrar satın alma niyeti yarattığını göstermektedir (Kumar ve Bhatnagar, 2017: 66-67). Qin ve Prybutok (2009: 90); fast food restoranlarında hizmet kalitesi, yiyecek kalitesi, algılanan değer, müşteri memnuniyeti ve davranışsal niyetler arasındaki ilişkileri incelemiş ve yiyecek-içecek kalitesinin müşteri memnuniyeti üzerinde olumlu ve doğrudan bir etkiye sahip olduğunu belirtmiştir. Benzer biçimde Hidayat vd., (2020: 1) tarafından yapılan bir diğer çalışmada yiyecek içecek kalitesi ile hizmet kalitesinin, müşteri memnuniyeti ve tekrar satın alma niyetine etkisinin olduğunu ortaya çıarmıştır. Bu durum yöneticilerine hizmetlerini farklılaştırmak için daha iyi stratejiler geliştirmeleri için destek sağlamaktadır. Yiyecek içecek kalitesi pek çok farklı özellikler kullanılarak kapsamlı şekilde ölçülmektedir. Buna göre gıda tazeliği, porsiyon büyüklüğü, menü çeşitliliği, yiyecek sunumu, yiyecek tadı ve sıcaklığı yaygın olarak kullanılan kalite boyutlarını oluşturmaktadır. Yazında yapılan pek çok araştırmada yiyecek tadının, yiyecek içecek kalitesinin en önemli özelliği olduğu belirtilmektedir (Hwang ve Ok, 2013: 123). Yiyecek içecek işletmelerinin faaliyet alanları ne olursa olsun müşteri 
beklentilerini karşılayamadıkları taktirde müşterilerin rakip işletmelere yönelmeleri kaçınılmaz olacaktır (Kılıç ve Kurnaz, 2012: 92).

Etkileşim Kalitesi: Etkileşim kalitesi; müşterilerin hizmet süreçleriyle karşılaşmaları durumunda hizmetin sunulma biçimine ilişkin algılarını ifade etmektedir. Etkileşim kalitesi aynı zamanda müşterilerin hizmet sunumu sırasında hizmet sağlayıcılarla (çalışanlar) etkileşim algılarıyla ortaya çıkmaktadır. Yazında yapılan araştırmalar kişilerarası etkileşimlerin, müşterilerin hizmet kalitesi algısı üzerinde kritik bir etkiye sahip olduğunu göstermektedir. Buna göre çalışanlar ve müşteriler arasındaki etkileşim kalitesi müşteri memnuniyeti üzerinde doğrudan bir etkiye sahip olmaktadır. Ayrıca müşterilerle ilişkiyi sürdürmek, müşteri memnuniyetinin öncüsüdür (Choi ve Kim, 2013: 190). Hizmetler doğası gereği soyut olduğundan, hizmet sunumu sırasında meydana gelen kişilerarası etkileşimler genellikle hizmet kalitesi algıları üzerinde en büyük etkiye sahiptir. Buna göre müşterilerim etkileşim kalitesi algısını oluşturan üç faktör bulunmaktadır. Bu faktörler; servis personelinin tutum, davranış ve uzmanlığı olarak belirtilmektedir. Bu bağlamda personelin arkadaş canlısı tavırlar göstermesi, bilgili yani alanında uzman olması ve müşteriler kapıdan girer girmez çalışanlar tarafından karşılanması etkileşim kalitesinin örgütsel yapılardaki bileşenlerini göstermektedir (Brady ve Cronin, 2001: 38). Etkileşim kalitesi; müşterilerde güven yarattığ1 ve davranışsal bağlılığı önemli ölçüde etkilediği için stratejik bir öneme sahiptir (Ioannou ve Melanthiou, 2015: 1).

Fiziksel Çevre Kalitesi: Müşterilerin yiyecek-içecek işletmelerinde karşılaştıkları fiziksel ortam, onların işletme hakkında ilk izlenimi edinmelerini sağlamaktadır. Bir hizmetin sunulduğu fiziksel ortam, tüketici psikolojisinin ve davranışının önemli bir belirleyicisi olmaktadır (Bengül ve Güven, 2019: 382). Mekânsal unsurların özellikleri fiziksel çevre kalitesi hakkında bilgi vermektedir. Buna göre; bir odanın boyutu, 1sı, ışık ve havalandırma özellikleri fiziksel çevre kalitesi olarak belirtilmektedir. Kotler (1973) fiziksel çevre kalitesini; satın alma olasılığını artırmak ve alıcılarda belirli etkiler yaratabilmek amacıyla mekânsal faktörlerin bilinçsel tasarımı olarak tanımlamıştır (Bhakar vd., 2013: 118). Fiziksel çevre kalitesi, müşteri tatmini üzerinde önemli bir etkiye sahip olup, müşterinin geri dönüş niyetinin belirlenmesinde önemli bir role sahiptir (Chang, 2000: 75). Fiziksel çevre kalitesi hem alışveriş yapanların hem de personelin davranışlarını etkilemekte ve satışları artırmaktadır. İşletmelerin sahip oldukları fiziksel çevrenin atmosferi, ürün değerlendirmesine ve müşteri memnuniyetine aracılık edebilmektedir. Müşterilerin işletmelerin fiziksel çevre kalitelerine yönelik tutumları, onların söz konusu işletmeleri tercih etmelerinde ürüne yönelik tutumlarından daha etkili olabilmektedir (Chebat ve Michon, 2003: 533). Ryu ve Han (2011: 607); fiziksel çevre kalitesinin müşteri tatminini ve sadakatini olumlu yönde etkilediğini belirtmiştir. Fiziksel çevre kalitesinin müşteriler gözünde beğenilmesi müşterilerin tekrar satın alma niyetlerinde ve söz konusu işletmeyi tavsiye etmelerinde önemli rol oynayacaktır.

\section{Müşteri Tatmini}

Günümüzde işletmeler, müşteri tatmini düzeylerini yükseltmek ve itibarlarını artırabilmek amacıyla müşteri ile olan ilişkilerini geliştirmeye çaba sarf etmektedirler. Bu kapsamda memnuniyet düzeyi yüksek olan işletmelerde müşteriyi elde tutma oranı artmakta, başarı düzeyleri yükselmekte ve müşteri ilişkileri daha uzun süreli olmaktadır. Hizmet özelliklerinde güvenilirlik, düzenlilik, uygunluk, lokasyon, güvenlik ve rahatlık müşteri tatmininde önemli rol oynayan faktörlerdir, söz konusu faktörlerin hepsinin hizmet kalitesine odaklanması müşteriler ile uzun süreli ilişkilerin kurulmasına zemin hazırlayacaktır (Kumar ve Bhatnagar, 2017: 66). Müşteri tatmini; hizmetlerin istek, beklenti ve ihtiyaçlarını karşılama kabiliyetinden kaynaklanan, tüketiciler tarafından algılanan genel memnuniyet veya memnuniyet düzeyi olarak 
tanımlanmaktadır (Hellier vd., 2003: 1765). Müşteri tatmini, ürün performansının müşteri beklentilerine uygun olduğu seviyedir. Ürünün performansı beklentileri karşılamadığında, müşteri hayal kırıklığına uğrayacak ve memnuniyetsizliğine yol açacaktır. Buna ilaveten ürünün performansı beklentileri aştığında müşteri tatmin olacaktır (Lestari ve Ellyawati, 2019: 159).

Müşteri memnuniyeti, işletmenin uzun vadede finansal istikrarını sağlamanın bir yoludur. Tekrarlanan satın alma davranışları ve müşteri sadakati ile hizmet kalitesi değiştiğinde müşteri tepkisi değerlendirilerek, müşterilerin memnuniyet düzeyleri belirlenebilir (Maroco ve Maroco, 2013: 120). Araştırmalar, müşteri tatmininin işletmeler üzerinde doğrudan ve dolaylı bir etkisi olabileceğini göstermektedir. Bu kapsamda müşteri memnuniyetinin işletme karlılığını olumlu yönde etkilediği belirtilmektedir. Müşteri memnuniyeti ile müşteri davranış kalıpları arasındaki ilişkiyi araştıran çeşitli araştırmalara göre, müşteri memnuniyeti müşteri sadakatini artırmakta, tekrar satın alma niyetlerini etkilemekte ve ağızdan ağıza olumlu iletişime yol açmaktadır (Nomnga ve Mhlanga, 2015: 2).

\section{Tekrar Satın Alma Niyeti}

İşletmelerin içsel ve dışsal özellikleri, ürün çeşitlilikleri, profesyonel kadroları, fiyatlandırma kararları, temizlik, konum, park alanları gibi özellikleri müşterilerin tekrar satın alma niyetleri üzerinde etkili olan unsurlardır. Buna ilaveten dekorasyon, aydınlatma, renk, sıcaklık, müzik, yiyecek içecek kalitesi ve hizmet süreçleri gibi müşterinin tekrar satın alma niyeti üzerinde etkili olan unsulardan bahsetmek mümkündür (Kumar ve Bhatnagar, 2017: 67). Müşteri tatmini, müşterinin söz konusu işletmeyi tekrar ziyaret ederek satın alma niyeti göstermesinde etkili olan önemli bir unsurudur. Çünkü tatmin düzeyi ne kadar yüksekse, müşterinin yeniden ziyaret etme olasılığı o kadar yüksek olacaktır.

Yazında müşteri tatmini ve tekrar satın alma niyeti arasındaki ilişkiyi destekleyen pek çok araştırma bulunmaktadır (Arlanda ve Suroso, 2018: 30). Buna göre Phuong ve Dai Trang (2018: 78); algılanan hizmet kalitesi ve müşteri memnuniyetinin tekrar satın alma niyeti üzerinde önemli bir olumlu etkisi olduğunu bildirmiştir. Soebandhi vd., (2020: 26); fiziksel çevre kalitesinin müşteri tatmini üzerinde daha güçlü bir etkiye sahip olduğunu ve müşterilerin tekrar satın alma niyetine yol açtığını ortaya koymaktadır. Başka bir araştırmada Mensah ve Dei Mensah (2018: 27); hem hizmet kalitesinin hem de müşteri tatmininin tekrar satın alma niyetinde önemli etkilere sahip olduğunu belirtmiştir. Wiranto ve Husin (2016: 77) ise müşteri tatminini sağlayan fiyat, hizmet kalitesi, ürün nitelikleri ve çevresel faktörlerin tekrar satın alma niyetiyle önemli ve olumlu bir şekilde ilişkili olduğunu açıklamıştır.

\section{Z Kuşağ1 ve Tüketici Davranışı}

Literatürde, 1995 yılı ve sonrasında doğanlar Z kuşağı olarak isimlendirilmişlerdir (Bassiouni ve Hackley, 2014: 117). En genç kuşak grubunu oluşturan Z kuşağının yaşamış olduğu farklı sosyal, tarihsel ve teknolojik faktörler, onların diğer kuşaklardan ayrılmalarını beraberinde getirmiştir (Levickaite, 2010: 173). Pazarlamacıların önem verdiği bir kuşak olan Z kuşağı, her konuda kişiselleşmiş, kendilerine özgü ve imaja dayanan bir tüketime yönelme davranışlarıyla dikkat çekmektedirler. Ĕgitim ve ekonomik açılardan diğer kuşak gruplarına göre daha donanımlı olan $\mathrm{Z}$ kuşağı, istediği her ürünü almayı, sonrasında hemen tüketmeyi ve akabinde ise yeni tüketim deneyimlerine yönelmeyi tercih etmektedir (Altuntuğ, 2012: 209).

Z kuşağı kişisel zevklerine düşkün ve çabuk tüketen özelliklere sahip olmaları nedeniyle, pek çok işletmenin hedef kitlesinde önemli bir yer edinmektedir. Bu kuşaktaki tüketiciler perakendecilere 
daha az sadıktır ve perakendecilerin ürünü kendilerine ulaştırmasını beklerler, bunun sonucunda perakendeciler tüketicilerin dikkatini çekmek ve onları elde tutmak için yeni yollar bulma konusunda baskı hissederler. Bu kuşağın daha yüksek beklentileri vardır, marka bağlllikları yoktur ve deneyimi daha çok önemserler. Bu özellikleri sebebiyle Z kuşağı işletmeler için bir meydan okuma olarak tanımlanmaktadır (Priporas vd., 2017: 376). Başka bir deyişle, Z kuşağının tüketim tercihlerinde diğer kuşak gruplarından farklılıklarının olacağı açıkça görülmektedir. Tüm bu bilgiler ışığında, işletmeler açısından $\mathrm{Z}$ kuşağını sadık müşteriler haline getirmenin çok daha zorlu bir süreç olduğu söylenebilir.

\section{YÖNTEM}

Araştırmanın temel amacı $\mathrm{Z}$ kuşağı bireylerin yiyecek-içecek işletmelerine yönelik hizmet kalitesi algılarını ve satın alma davranışlarını incelemektir. Bu amaç doğrultusunda $\mathrm{Z}$ kuşağı arasında popüler olan "kahve tüketimi alışkanlığı" seçilmiş ve hizmet kalitesinin tekrar satın alma niyeti üzerindeki etkisinde müşteri tatmininin aracllık etkisinin incelenmesi amaçlanmıştır.

\section{Araştırma Modeli ve Hipotezler}

Çalışmanın giriş ve literatür taraması bölümünde tartışılan ve alan yazınındaki bilgiler temelinde oluşturulmuş olan araştırma modeline Şekil 1'de yer verilmiştir.

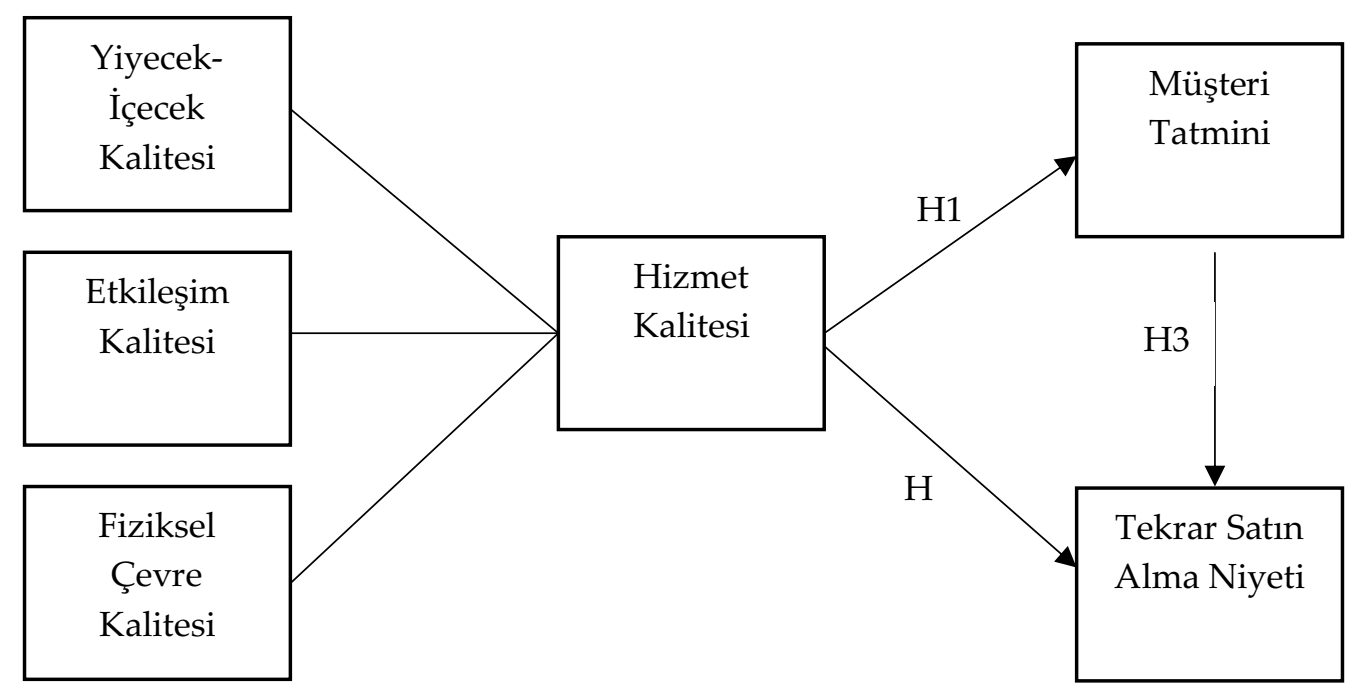

Şekil 1. Araştırma Modeli

Literatür taraması sonucu elde edilen bulgulardan ve teoriden yola çıkılarak bu çalışmada dört hipotez oluşturulmuştur:

H1: Hizmet kalitesi müşteri tatminini pozitif yönde etkiler.

$\mathbf{H}_{2}$ : Hizmet kalitesi tekrar satın alma niyetini pozitif yönde etkiler.

$\mathbf{H}_{3}$ : Müşteri tatmini tekrar satın alma niyetini pozitif yönde etkiler.

$\mathbf{H}_{4}$ : Hizmet kalitesi ile tekrar satın alma niyetini arasındaki ilişkide müşteri tatmininin aracılık rolü vardır. 


\section{Araştırmanın Evreni, Örneklem ve Veri Toplama Yöntemi}

Araştırmanın evreni Z kuşağı kahve tüketicisi bireylerden oluşmaktadır. Bu çalışma keşifsel amaçlı olduğundan, veri toplamak için mümkün olan en iyi strateji olarak anket seçilmiştir. Anket uygulaması 1 Aralık - 31 Aralık 2019 tarihleri arasında Çanakkale kent merkezinde yer alan iki adet Starbucks kahve dükkanından ürün satın alan $Z$ kuşağı bireylerle yüz yüze gerçekleştirilmiş ve kullanılabilir 621 anket elde edilmiştir. Araştırma kapsamında veriler, zaman ve maliyet kısıtları sebebiyle tesadüfi olmayan örneklem tekniklerinden kolayda örneklem tekniği ile anlık olarak toplanmıştır.

Araştırmada kullanılan anket formu iki bölümden oluşmaktadır. Birinci bölümde demografik özellikler, ikinci bölümde araştırma modelinde kullanılan değişkenlere ait sorular yer almaktadır. İkinci bölümde, Brady ve Cronin (2001) ile Chen ve Hu (2010)'nun çalışmalarından uyarlanan yiyecek ve içecek kalitesi, fiziksel çevre kalitesi ve etkileşim kalitesi soruları sırasıyla 5, 4 ve 3 ifadeden oluşmaktadır. Bu kapsamda hizmet kalitesi boyutu 12 ifadeyle ölçülmüştür. Müşteri tatminini ölçmek için Kim, Kim ve Holland (2018)'in çalışmasında kullanılan ölçekten yararlanılmıştır, ölçek 3 ifaden oluşmaktadır. Tekrar satın alma niyetini ölçmek için Kim ve Moon (2009)'un çalışmasında kullanılan ölçekten yararlanılmıştır, ölçek 3 ifadeden oluşmaktadır. Katılımcılardan bu ifadelere 5'li Likert ölçeği (1- Kesinlikle Katılmıyorum; 5- Kesinlikle Katılıyorum) çerçevesinde yanıt vermesi istenmiştir.

\section{BULGULAR}

Araştırmanın amacı temelinde elde edilen verilerin analizi sonucu katılımcıların demografik özellikleri, ölçeklerin güvenilirlik ve geçerlikleri ile hipotez sonuçlarına dair bulgular bu bölümde detaylı olarak açıklanmıştır.

\section{Demografik Özellikler}

Araştırmaya katılanların demografik özelliklerine ilişkin bilgiler Tablo 1'de gösterilmiştir.

Tablo 1 incelendiğinde araştırma katılımcılarının çoğunluğunun kadın $(\% 56,2)$ ve üniversite öğrenci olduğu $(\% 71,3)$ görülmektedir. Katılımcıların yaş aralığının 16 ile 24 arasında değiştiği de bir diğer bilgi olarak yer almaktadır. Bu yaş aralığının $\mathrm{Z}$ kuşağı içerisindeki en aktif tüketici kitlesini oluşturduğu söylenebilir. Ankete katılanlara aylık ortalama yiyecek-içecek harcamalarına yönelik yöneltilen soruya katılımcların yarısına yakınını 501 ila 1000 Türk lirası $(\% 48,6)$ arası cevabını vermiştir.

Tablo 1. Demografik Özellikler

\begin{tabular}{|c|c|c|c|c|c|}
\hline Demografik Özellikler & $\mathbf{n}$ & $\%$ & Demografik Özellikler & $\mathbf{n}$ & $\%$ \\
\hline \multicolumn{3}{|l|}{ Cinsiyet } & \multicolumn{3}{|l|}{ Öğrenim Durumu } \\
\hline \multirow{3}{*}{$\begin{array}{l}\text { Kadin } \\
\text { Erkek } \\
\text { Toplam }\end{array}$} & 349 & 56,2 & Lise Öğrencisi & 178 & 28,7 \\
\hline & 272 & 43,8 & Üniversite Öğrencisi & 443 & 71,3 \\
\hline & 621 & 100,0 & Toplam & 621 & 100,0 \\
\hline \multicolumn{3}{|l|}{ Yaş Aralığı } & \multicolumn{3}{|l|}{ Aylık Ortalama Harcama } \\
\hline $16-18$ & 108 & 17,4 & $500 \mathrm{TL}$ den az & 205 & 33,1 \\
\hline $19-21$ & 395 & 63,6 & $501-1000 \mathrm{TL}$ & 302 & 48,6 \\
\hline $22-24$ & 118 & 19,0 & $1001-1500 \mathrm{TL}$ & 114 & 20,3 \\
\hline Toplam & 621 & 100 & Toplam & 621 & 100,0 \\
\hline
\end{tabular}




\section{Araştırma Modelinin Analizi}

Yazın taraması sonucunda oluşturulan araştırma modelinin analizi için, KEKK-YEM (Kısmi En Küçük Kareler Yapısal Eşitlik Modellemesi) yöntemi ile SmartPLS 3.3.3. paket programı kullanılmıştır. KEKK-YEM, geleneksel kovaryans tabanlı YEM 'den farklı olarak varyans temelli ve parametrik olmayan koşullar altında gizli yapıları modelleme yeteneği nedeniyle son on yılda pazarlama araştırmasında giderek daha popüler hale gelmiştir (Ali vd., 2017: 364). Bu özel yöntem otelcilik ve turizm alanındaki son çalışmalarda da yapısal araştırma modellerini analiz etmek için kullanılmaktadır (Ali vd., 2018: 514). SmartPLS programında analizler iki aşamada gerçekleştirilmektedir. İlk aşamada araştırma modeli, ölçüm modeli (dış model) kullanılarak modelindeki değişkenlerin geçerlik ve güvenirlilik analizleri yapılmaktadır. İkinci aşamada ise yapısal model (iç model) kullanılarak bağımsız ve bağımlı gizil değişkenler arasındaki ilişkiler belirlenmektedir (Yıldız, 2020: 26).

\section{Ölçeklerin Geçerlik ve Güvenirlik Analizleri}

Araştırmanın ölçüm modelinin geçerliliği ve güvenilirliğinin değerlendirilmesinde iç tutarlılık güvenirliği, birleşme geçerliği ve ayrışma geçerliği değerlendirilmiştir. İç tutarlılık güvenirliği için Cronbach Alfa ve birleşik güvenirlik ( $\mathrm{CR}=$ Composite Reliability) katsayıları incelenmiştir. Birleşme geçerliğinin tespitinde, faktör yükleri ile açıklanan ortalama varyans (AVE=Average Variance Extracted) değerleri kullanılmıştır. Faktör yüklerinin $\geq 0,70$; Cronbach Alpha ve birleşik güvenirlik katsayılarının $\geq 0,70$; açıklanan ortalama varyans değerinin de $\geq 0,50$ olarak gerçekleşmesi beklenmektedir (Hair vd., 2016; Fornell ve Larcker, 1981). Aşağıda yer alan Tablo 2 'de araştırmada yer alan yapıların iç tutarlılık güvenirliği ve birleşme geçerliği ile ilgili sonuçlar yer almaktadır.

Yapıların, Cronbach Alfa katsayılarının 0,773 ile 0,923 arasında; CR katsayılarının da 0,868 ile 0,937 arasında gerçekleşmiş olması nedeniyle iç tutarlılık güvenirliğinin sağlandığı söylenebilir. Tablodaki değerler incelendiğinde, faktör yüklerinin 0,691 ile 0,928 arasında gerçekleştiği görülmektedir. Hair, vd., (2016)'ya göre faktör yükleri $\geq 0,708$ olmalıdır. Yazarlar, faktör yükleri 0,40 ile 0,70 arasında olan ifadelerin AVE ya da CR değerlerinde yükselme olması durumunda modelden çıkarılmasını önermektedir. Hesaplanan AVE ve CR değerlerinin eşik değerlerin üzerinde olması nedeniyle faktör yükü 0,708 'in altında olan yiyecek-içecek kalitesinin beş numaralı ifadesi ölçekten çıkartılmamıştır. Yapıların, faktör yüklerinin 0,691 ile 0,928 arasında; AVE değerlerinin de 0,687 ile 0,858 arasında olması nedeniyle birleşme geçerliğinin sağlandığı belirtilebilir.

Ayrışma geçerliliğinin tespitinde, Fornell ve Larcker (1981) tarafından önerilen kriter ile Henseler vd., (2015) tarafından önerilen HTMT (Heterotrait-Monotrait Ratio), kriterleri kullanılmıştır. Fornell ve Larcker (1981) kriterine göre, araştırmada yer alan yapıların AVE değerlerinin karekökü, araştırmada yer alan yapılar arasındaki korelasyonlardan yüksek olmalıdır. Tablo 3'te Fornell ve Larcker (1981) kriterine göre yapılan analiz sonuçları yer almaktadır. 
Tablo 2. Ölçüm Modeli Sonuçları

\begin{tabular}{|c|c|}
\hline Yapılar/İfadeler & Faktör Yükü \\
\hline \multicolumn{2}{|l|}{ Yiyecek-İçecek Kalitesi $\alpha=0.867 ; \mathrm{CR}=0.905 ; \mathrm{AVE}=0.858$} \\
\hline Starbucks'ta kahvenin kalitesi iyidir. & 0,870 \\
\hline Starbucks'ta kahvenin tadı iyidir. & 0,890 \\
\hline Starbucks'ta kahvenin saflığı iyidir. & 0,847 \\
\hline Starbucks'ta kahve dışındaki içeceklerin kalitesi iyidir. & 0,739 \\
\hline Starbucks'ta yiyeceklerin ve tatlıların kalitesi iyidir. & 0,691 \\
\hline \multicolumn{2}{|l|}{ Etkileşim Kalitesi $\alpha=0.854 ; \mathrm{CR}=0.902 ; \mathrm{AVE}=0.697$} \\
\hline Starbucks'ta hizmet hizlıdır. & 0,796 \\
\hline Starbucks çalışanları nazik ve cana yakındır. & 0,839 \\
\hline Starbucks çalışanları işlerinde özenlidir. & 0,881 \\
\hline Starbucks'ta temizlik ve hijyene önem verilir. & 0,820 \\
\hline \multicolumn{2}{|l|}{ Fiziksel Çevre Kalitesi $\alpha=0.773$; CR=0.868; AVE $=0.687$} \\
\hline Starbucks'in dekorasyonu etkileyicidir. & 0,813 \\
\hline Starbucks'in sicak bir ortamı vardır. & 0,855 \\
\hline $\begin{array}{l}\text { Starbucks'ın benim dışındaki müşterilerine de iyi bir izlenim bıraktığını } \\
\text { gördüm. }\end{array}$ & 0,819 \\
\hline \multicolumn{2}{|l|}{ Müşteri Tatmini $\alpha=0.874 ; \mathrm{CR}=0.923 ; \mathrm{AVE}=0.799$} \\
\hline Genel olarak, Starbucks ‘tan memnun kaldım. & 0,893 \\
\hline $\begin{array}{l}\text { Starbucks'daki satın alma deneyimimden beklentilerime göre } \\
\text { memnunum. }\end{array}$ & 0,899 \\
\hline $\begin{array}{l}\text { Harcadığım zaman ve çabayı göz önünde bulundursam, Starbucks'a } \\
\text { gitmekten memnunum. }\end{array}$ & 0,889 \\
\hline \multicolumn{2}{|l|}{ Tekrar Satın Alma Niyeti $\alpha=0.899 ; \mathrm{CR}=0.937$; AVE=0.832 } \\
\hline Starbucks'a yakın zamanda tekrar gelmek istiyorum. & 0,927 \\
\hline $\begin{array}{l}\text { Sevdiklerimle birlikte Starbucks'a tekrar gitmek için güçlü bir niyetim } \\
\text { var. }\end{array}$ & 0,928 \\
\hline Starbucks diğer kahve dükkanları içerisinde ilk tercihimdir. & 0,881 \\
\hline
\end{tabular}

Tablo 3. Ayrışma Geçerliliği Sonuçları (Fornell ve Larckell Kriteri)

\begin{tabular}{|c|c|c|c|c|c|}
\hline & 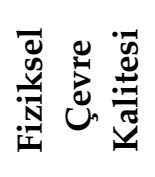 & 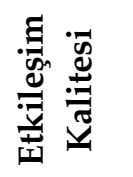 & 悹 & 莺 & 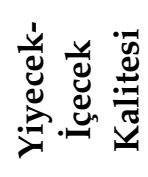 \\
\hline Fiziksel Çevre Kalitesi & $(0,829)$ & & & & \\
\hline Etkileşim Kalitesi & 0,685 & $(0,835)$ & & & \\
\hline Müşteri Tatmini & 0,714 & 0,719 & $(0,894)$ & & \\
\hline Tekrar Satın Alma Niyeti & 0,639 & 0,600 & 0,779 & $(0,912)$ & \\
\hline Yiyecek-İçecek Kalitesi & 0,706 & 0,701 & 0,766 & 0,675 & $(0,811)$ \\
\hline
\end{tabular}

Tablodaki parantez içindeki değerler AVE'nin karakök değerleridir. Tablodaki değerler incelendiğinde her bir yapının açıklanan ortalama varyans karekökünün diğer yapılarla korelasyonundan daha yüksek olduğu görülmektedir. Henseler vd., (2015)'nin kriterine göre 
HTMT araştırmada yer alan tüm değişkenlere ait ifadelerin korelasyonlarının ortalamasının aynı değişkene ait ifadelerin korelasyonlarının geometrik ortalamalara oranlarını ifade etmektedir. Yazarlar HTMT değerinin; içerik olarak yakın kavramlarda 0,90'nın, içerik olarak birbirine uzak kavramlarda ise $0,85^{\prime}$ in altında olmasını gerektiğini belirtmişlerdir. Tablo $4^{\prime}$ te de HTMT değerlerine yer verilmiştir.

Tablo 4. Ayrışma Geçerliliği Sonuçları (HTMT Kriteri)

\begin{tabular}{|c|c|c|c|c|c|}
\hline & 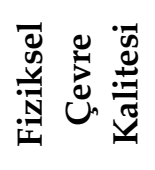 & 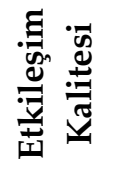 & 悹 & 売 & 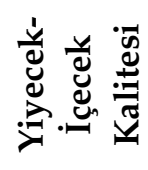 \\
\hline \multicolumn{6}{|l|}{ Fiziksel Çevre Kalitesi } \\
\hline Etkileşim Kalitesi & 0,838 & & & & \\
\hline Müşteri Tatmini & 0,866 & 0,833 & & & \\
\hline Tekrar Satın Alma Niyeti & 0,763 & 0,684 & 0,873 & & \\
\hline Yiyecek-İçecek Kalitesi & 0,859 & 0,813 & 0,875 & 0,759 & \\
\hline
\end{tabular}

Tablodaki değerler incelendiğinde HTMT değerlerinin eşik değerin altında olduğu görülmektedir. Tablo 3 ve Tablo 4'teki bulgulara dayanarak ayrışma geçerliğinin sağlandığ belirtilebilir.

\section{Yapisal Model}

Ölçüm modelinin geçerlilik ve güvenirlik testlerinin kabul görmesiyle, araştırmanın yapısal eşitlik analizini yapmak üzere yine SmartPLS 3.3.3 paket programı kullanılmış ve analiz sonrası yapısal modele ait sonuçlar Şekil 2'de gösterilmiştir. Bu araştırmada üç boyutlu olan hizmet kalitesi bağımsız değişkeni SmartPLS 3.3.3 paket programında tek boyuta indirgenmiş ve yapısal model üst düzey model olarak test edilmiştir. Üst düzey model genellikle ikinci derece iki yapı katmanı içeren modellerin test edilmesinde kullanılmaktadır. Araştırmada üst düzey model, değişkenler arasında doğrusallık problemi oluşmaması ve modeldeki ilişki sayılarının azaltılması (Yıldız, 2020: 173) amaciyla kullanılmıştır.

Araştırma modeline ilişkin; doğrusallık, yol katsayıları, $\mathrm{R}^{2}$ ve etki büyüklüğünü $\left(\mathrm{f}^{2}\right)$ hesaplamak için PLS algoritması; tahmin gücünü $\left(\mathrm{Q}^{2}\right)$ hesaplamak için de Blindfolding analizi çalıştırılmıştır. Tablo 5'te; VIF, R², f² ve $\mathrm{Q}^{2}$ katsayıları gösterilmiştir. 


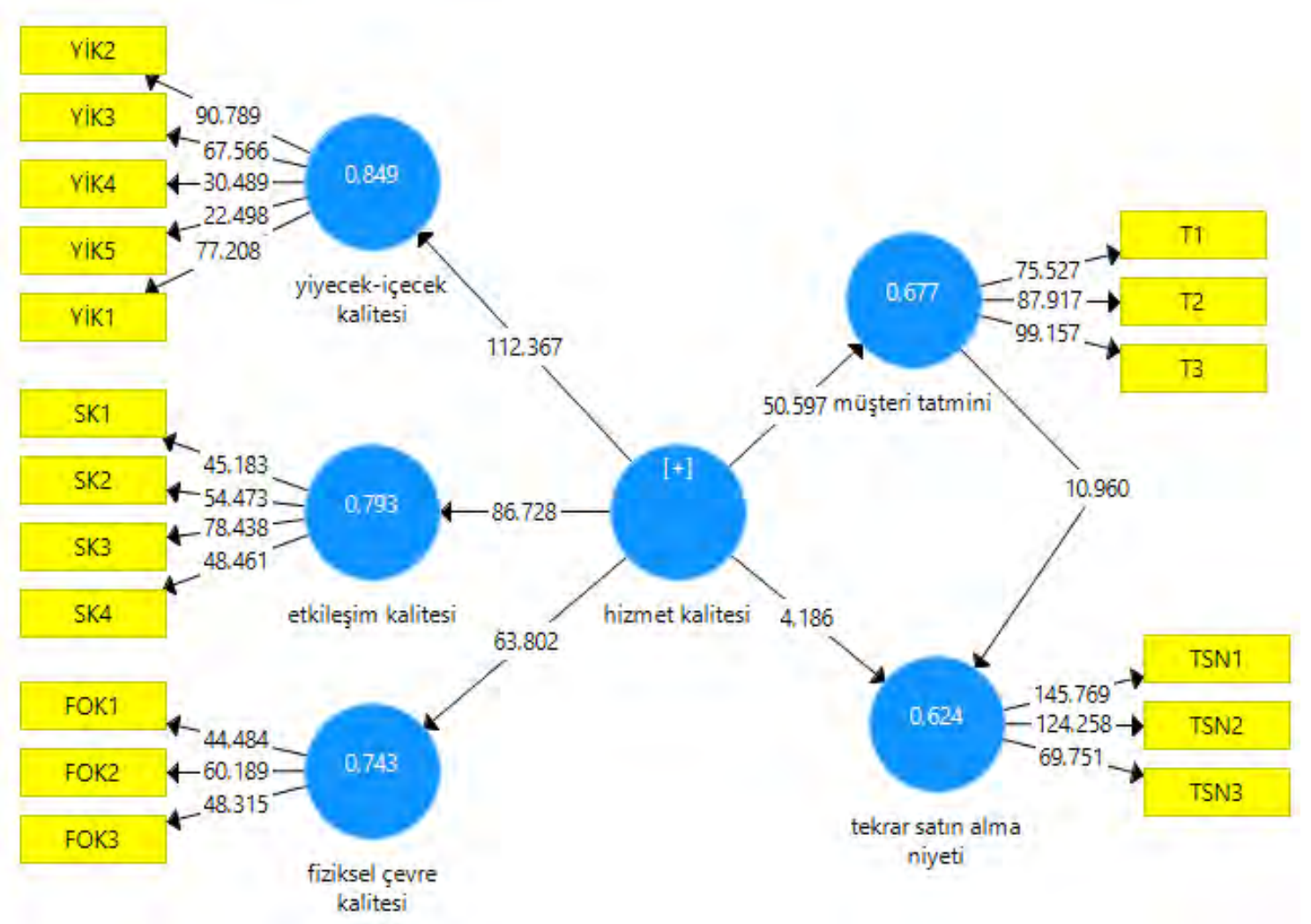

Şekil 2. Yapısal Eşitlik Modeli

Tablo 5. Araştırma Modeli Katsayıları

\begin{tabular}{|l|l|c|c|c|c|}
\hline \multicolumn{2}{|l|}{ Değişkenler } & VIF & $\mathbf{R}^{2}$ & $\mathbf{f}^{2}$ & $\mathbf{Q}^{\mathbf{2}}$ \\
\hline Hizmet Kalitesi & Müşteri Tatmini & 1,000 & 0,677 & 2,099 & 0,538 \\
\hline Hizmet Kalitesi & Tekrar Satın Alma Niyeti & 3,099 & 0,624 & 0,046 & 0,514 \\
\hline Müşteri Tatmini & Tekrar Satın Alma Niyeti & 3.099 & 0,624 & 0,298 & 0,514 \\
\hline
\end{tabular}

KEKK-YEM yönteminde iç modelin değerlendirilmesinde modelin açılayıcı gücünü ölçmek için determinasyon katsayısı olan $\mathrm{R}^{2}$ değeri kullanılmaktadır. $\mathrm{R}^{2}$ değeri 0 ile 1 değeri arasında değer almakta ve 0,25 ve üzeri zayıf, 0,50 ve üzeri orta ve 0,75 ve üzeri ise güçlü bir açıklama oranı olarak değerlendirilmektedir (Henseler vd., 2015). Tablo 5'te yer alan $\mathrm{R}^{2}$ değerleri incelendiğinde müşteri tatmininin \%68 tekrar satın alma niyetini de \%63 oranında açılandığ 1 tespit edilmiştir.

Etki büyüklüğü (f²) katsayısı ise her bağımsız değişken için hesaplanır. $\mathrm{f}^{2}$ katsayısı, bağımsız değişkenlerin bağımlı değişkenlerin açıklanma oranının paylarını göstermektedir (Yıldız, 2020). Etki büyüklügü katsayısının ( $\left.f^{2}\right)$ 0,02 ve üzeri olması düşük; 0,15 ve üzeri olması orta; 0,35 ve üzeri olması ise yüksek olarak değerlendirilmektedir (Cohen, 1988). Sarstedt, Ringle ve Hair (2017)'ye göre de katsayının 0,02'nin altında geçekleştiği durumlarda da bir etkiden söz etmenin mümkün olmadığı belirtilmiştir. Etki büyüklüğü $\left(f^{2}\right)$ katsayıları incelendiğinde hizmet kalitesinin müşteri tatmini üzerinde yüksek, müşteri tatmininin tekrar satın alma niyeti üzerinde orta, hizmet kalitesinin tekrar satın alma niyeti üzerinde ise düşük seviyede etki büyüklügüune sahip olduğu görülmüştür. 
Bağımlı değişkenler için hesaplanan tahmin gücü katsayılarının $\left(\mathrm{Q}^{2}\right)$ sıfırdan büyük olması, araştırma modelinin, bağımlı değişkenleri tahmin gücüne sahip olduğunu göstermektedir (Hair vd., 2016). Tablodaki $\mathrm{Q}^{2}$ değerlerinin sıfırdan büyük olması nedeniyle araştırma modelinin tahmin gücüne sahip olduğu belirtilebilir.

Son olarak Hair vd., (2016)'ya göre, değişkenler arasında doğrusallıkla ilgili bir problem olmaması açısından VIF (Variance Inflation Factor) katsayıları eşik değer olan 5'in altında gerçekleşmelidir. Tablo 5'teki VIF katsayıları 5'in altında olduğu için değişkenler arasında doğrusallık sağlanmasına dair bir problem söz konusu değildir.

Araştırmaya ilişkin $\mathrm{t}$ değerlerinin ve anlamlılıklarının hesaplanması için araştırma modeli üzerinde Bootstrap yöntemi kullanılmıştır. Türev örnekleme ile örneklemden 5000 alt örneklem alınarak $\mathrm{t}$ değerleri hesaplanmıştır. Tablo 6 'da araştırma modeline dair etkilere yönelik sonuçlar gösterilmiştir.

Tablo 6. Araştırma Modeli (Hipotez Testleri)

\begin{tabular}{|c|c|c|c|c|c|c|}
\hline \multicolumn{3}{|l|}{ Değişkenler } & $\begin{array}{l}\text { Standardize } \\
\beta\end{array}$ & S.S. & $t$ değeri & $\mathbf{p}$ \\
\hline Hizmet Kalitesi & \multicolumn{2}{|c|}{ Müşteri Tatmini } & 0,823 & 0,016 & 50,597 & 0,000 \\
\hline Hizmet Kalitesi & \multicolumn{2}{|c|}{ Tekrar Satın Alma Niyeti } & 0,715 & 0,021 & 4,186 & 0,000 \\
\hline Müşteri Tatmini & \multicolumn{2}{|c|}{ Tekrar Satın Alma Niyeti } & 0,589 & 0,054 & 10,960 & 0,000 \\
\hline Hizmet Kalitesi & $\begin{array}{l}\text { Müssteri } \\
\text { Tatmini }\end{array}$ & $\begin{array}{l}\text { Tekrar Satın } \\
\text { Alma Niyeti }\end{array}$ & 0,485 & 0,047 & 10,224 & 0,000 \\
\hline
\end{tabular}

Aracılık etkisinin araştırılması için ilk aşamada aracı değişken araştırma modelinden çıkarılarak yol katsayılarının anlamlılığı test edilmiştir. Hizmet kalitesinin tekrar satın alma niyetini $(\beta=0,715 ; p<0,01)$ etkilediği tespit edilmiştir. Bu bulgulara dayanarak araştırmanın 2 numaralı hipotezi desteklenmiştir.

İkinci aşamada ise aracı değişken modele dahil edilerek yol katsayılarının anlamlılığ test edilmiştir. Hizmet kalitesinin müşteri tatminini $(\beta=0,832 ; p<0,01)$ ve müşteri tatmininin tekrar satın alma niyetini $(\beta=0,589 ; p<0,01)$ etkilediği tespit edilmiştir. Dolayısıyla araştırmanın 1 ve 3 numaralı hipotezleri de desteklenmiştir. Dolaylı etkiler incelendiğinde hizmet kalitesinin; tekrar satın alma niyetini $(\beta=0,485 ; p<0,01)$ müşteri tatmini üzerinden de etkilediği gözlemlenmiştir.

Baron ve Kenny (1986) bir aracılık etkisinin söz konusu olabilmesi için, bağımsız değişkenlerin bağımlı değişkenler üzerinde anlamlı etkileri olması gerektiğini belirtmişlerdir. Aynı zamanda modele aracı değişkenler dahil edildiğinde de bağımsız değişkenlerin aracı değişkenler, aracı değişkenlerinde bağımlı değişkenler üzerinde anlamlı etkileri olmalıdır. Bağımsız değişkenin bağımlı değişken, bağımsız değişkenin aracı değişken ve aracı değişkenin tekrar satın alma niyeti üzerindeki anlamlı etkisi nedeniyle aracılık etkisinden söz edilebilir.

Aracılık etkisinin tespit edilmiş olması nedeniyle VAF (Variance Accounted For) değerleri hesaplanmıştır. VAF $>0,80$ ise tam aracı etki; $0,20 \leq \mathrm{VAF} \geq 0,80$ ise kısmi aracı etki bulunmaktadır. $\operatorname{VAF}<0,20$ ise aracı etkiden söz edilemez (Doğan, 2018). VAF değerleri Hizmet Kalitesi $\rightarrow$ Müşteri Tatmini $\rightarrow$ Tekrar Satın Alma Niyeti yolunda 0,40 olarak hesaplanmıştır. Bu doğrultuda araştırmanın 4 numaralı hipotezi de desteklenmiştir. Ayrıca, hizmet kalitesi ile tekrar satın alma niyeti arasındaki ilişkide müşteri tatmininin kısmi aracılık rolü bulunduğu tespit edilmiştir. 
Modele ait elde edilen $\mathrm{R}^{2}$ değerleri incelendiğinde ise tekrar satın alma niyetinin aracı değişkenin olmadığı modelde \%51, aracı değişkenin olduğu modelde de \%63 oranında açıklandığı tespit edilmiştir. $\mathrm{R}^{2}$ değerindeki artış, tespit edilen aracılık rolünün bir teyidi olarak değerlendirilebilir.

\section{SONUÇ ve ÖNERILLER}

Kahve, dünyadaki en popüler içeceklerden biridir. Genel olarak sosyal etkinliklerde alkollü içeceklere sağlıklı bir alternatif olduğu varsayılmaktadır. Ancak neredeyse günümüze kadar kahve, yetişkin içeceği olarak klişeleşmiş̧ir. Son yıllarda hem dünyada hem de ülkemizde bu alg1 değişmekte ve kahve işletmeleri popüler tüketim kültürünün odağı haline gelmekte ve genç tüketiciler tarafından da tercih edilmektedir. Ülkemizde özellikle Starbucks gibi kahve dükkânı sayısı büyük ölçüde artış göstermiş ve çok sayıda benzersiz ve özel kahve dükkânları açılmıştır. Sayıları giderek artan yerli ve yabancı kahve dükkânlarını tercih eden tüketiciler için önemli olan yalnızca kahve içmek değil aynı zamanda rahat bir ortamda bulunmak, arkadaşlarla vakit geçirmek ve işletmenin diğer ürünlerini de tüketmek olmaya başlamıştır (Bayındır ve Yüncü, 2020: 3140). Farklı çalışmalar kahve dükkânlarının ders çalışmak, işle ilgili çalışmak ve oyun oynamak için de kullanıldığını göstermektedir. Müşterilerin kahve tüketimindeki bu tür yeni alışkanlıkları, kahve endüstrisinin büyümesine önemli ölçüde katkıda bulunmuştur (Sasongko vd., 2020: 107).

Tüm dünyada kahve endüstrisindeki önemli büyümeye rağmen, ilgili alan yazınında kahve işletmeleri bağlamında müşteri tatminini etkileyen değişkenlerin kullanımı oldukça sınırlı kalmaktadır (Lee vd., 2018:636). Diğer yandan yiyecek-içecek sektöründe her işletmenin başarısının ve hayatta kalmasının, performansına ve müşterilerinin bu konudaki bakış açısına bağlı olduğu bilinmektedir. Satın almayı seçen ve gelecekte satın almalarını tekrarlamaya karar veren sadık müşteriler işletmeyi daha başarılı kılmakta ve bu da işletmenin rekabetçi bir pazarda hayatta kalmasına yardımcı olmaktadır (Namin, 2017: 70). Bu nedenle bu sektörde hizmet kalitesi, müşteri tatmini ve satın alma sonrası niyetler arasındaki ilişkinin incelenmesi oldukça önem arz etmektedir. Ayrıca, bu sektörün önemli bir üyesi olan kahve dükkânı endüstrisinin gelişiminin, $\mathrm{Z}$ kuşağı olarak tanımlanan genç nesil için yeni bir hizmet deneyimi yarattığ görülmektedir. Ancak, Z kuşağı örnekleminde yapılan araştırmaların sayısı kısıtlı kalmıştır. Bu kapsamda, araştırmada yazındaki boşluğunu doldurmak için, Z kuşağı tüketiciyle ilgili hizmet kalitesi, müşteri tatmini ve tekrar satın alma niyeti arasındaki istatistiksel ilişki incelenmiştir.

Çalışmada örnekleme kolaylığından dolayı araştırma konusu olarak Starbucks kahve zinciri seçilmiştir. En büyük kahve dükkânı zinciri olan Starbucks, çeşitli ürünler (örneğin içecekler, yiyecek, çay ve kahve ile ilgili ürünler) sağlar ve yiyecek ve içecek endüstrisinde pazar lideridir (Lee vd., 2018:629). Bu kapsamda çalışmanın bulgularının hem genelde yiyecek-içecek işletmelerinin hem de özel kahve alanında hizmet sunan işletmelerin müşterilerini anlamasına hizmet etmesi amaçlanmışır. Araştırmada dört hipotez önerilmiş ve test edilmiştir. Öncelikle, çalışmanın sonuçları Huang vd., (2014) tarafından 12 kahve zinciri işletmesinde gerçekleştirilen hizmet kalitesinin kahve dükkânı müşterilerinin tatminini olumlu yönde etkilediğini ortaya çıkaran çalışmasıyla benzerlik göstermektedir. Yine Quintao ve Prasonnguskarn (2017)'nin çalışma örneklemi olarak Starbucks kahve işletmesini seçtiği ve hizmet kalitesinin tekrar ziyaret etme eğilimini olumlu yönde etkilediği sonucuna ulaştıkları araştırmalarılyla uyumlu bulgulara ulaşmıştır. İkinci olarak, bu çalışma önceki çalışmalarla tutarlı olarak kahve dükkânı hizmeti bağlamında tatmin ve tekrar satın alma niyeti arasında olumlu bir bağlantı olduğunu göstermiştir (Han ve Ryu, 2009; Kim vd., 2015). Son olarak araştırma, müşteri tatmininin hizmet kalitesi ile tekrar ziyaret etme eğilimi arasındaki ilişkide aracılık rolünü ortaya çıkarmıştır. Ayrıca çalışmada, yiyecek-içecek işletmelerinde hizmet kalitesinin öncüllerinden olan sırasıyla; yiyecek- 
içecek kalitesinin önemi konusunda, çalışanların tutumunu yansıtan etkileşim kalitesi konusunda ve işletmenin atmosferinin önemini ortaya koyan fiziksel çevre kalitesi hakkında bilgi sunulması, çalışmanın diğer teorik katkıları arasında yer almaktadır.

Çalışmanın genelde yiyecek-içecek işletmeleri özelde ise kahve dükkânı yöneticileri için uygulamaya dönük çıkarımları da bulunmaktadır. İlk olarak $\mathrm{H}_{1}$ ve $\mathrm{H}_{2}$ hipotez sonuçları hizmet kalitesinin müşteri tatminini ve tekrar satın alma niyetini önemli ölçüde ve doğrudan etkilediğini göstermektedir. Hizmet kalitesinin önemi ve bu çalışmada ele alınan alt boyutları göz önüne alındığında, her bir boyuta eş düzeyde önem verilmesi gerektiği söylenebilir. Kahve dükkânı yöneticilerinin işletmelerini tanıtmada ve pazarlamada başta kahve olmak üzere yiyecek-içecek kalitesini kilit bir unsur olarak ele almaları ancak iyi hizmet sağlamak için etkileşim kalitesi kapsamında iletişim becerileri, samimiyet ve ürün bilgisi konusunda personel eğitimi uygulamalarını da muhakkak yer vermeleri tavsiye edilmektedir. Benzer biçimde, yöneticilerin atmosfer, müzik ve dekorasyon gibi fiziksel çevreyle ilgili unsurlara ve müşterileri için rahat ve temiz bir ortam yaratmaya odaklanması önerilmektedir.

Müşteri tatmini ile tekrar satın alma niyeti $\left(\mathrm{H}_{3}\right)$ arasındaki doğrudan ve anlamlı ilişki, kahve dükkânı yöneticilerinin müşteri tatminini artırarak işletmelerine dönen ve tekrar satın alan müşterilere odaklaması gerektiğini göstermektedir. Başka bir deyişle, müşteri tatmini müşteri sadakatine dönüşerek tekrar satın alma niyetine yol açmakta ve hatta olumlu ağızdan ağıza yayılmaya da yol açabilmektedir. Ayrıca, bu durum işletme için daha iyi finansal getiriler de sağlayabilir. Bu kapsamda yöneticilerin müşteri tatmini oluşturmayı temel iş stratejisi olarak benimsemelerinin gerekliliği ortaya konmuştur. Yukarıda tartışıldığı gibi diğer iki hipotezin sonuçları kahve dükkânı yöneticilerinin hizmet kalitesinden müşteri memnuniyeti oluşturmada ve dolayısıyla olumlu davranışsal niyetler geliştirme de kilit bir yönetim politikası olarak yararlanabileceği gerçeğini desteklemektedir.

Daha önce de belirtildiği gibi araştırmanın örneklemi yalnızca Çanakkale kent merkezinde yer alan Starbucks kahve dükkanlarından hizmet alan Z kuşağı müşterilerden oluşmaktadır. Bu sınırlamanın üstesinden gelmek için, gelecekteki araştırmalarda daha geniş örneklerden (ek kahve zinciri işletmelerini ve/veya özel markalı kafeler) elde edilen sonuçlar karşılaştırmalıdır. Bu nedenle, çalışmanın sonuçları bu popülasyonun ötesinde genelleştirilemez. Bununla birlikte, Starbucks küresel olarak kahve endüstrisinde lider olmaya devam ettiğinden, çalışmanın bulguları Starbucks'ın izinden gitmek isteyen diğer yiyecek-içecek markalarına ve ayrıca yiyecekiçecek işletmeleri açısından $\mathrm{Z}$ kuşağının tüketim davranışlarına yönelik fikir verebilir.

\section{KAYNAKÇA}

Ali, F., Hussain, K., Konar, R. and Jeon, M. (2017). The Effect of Technical and Functional Quality on Guests' Perceived Hotel Service Quality and Satisfaction: A SEM-PLS Analysis. Journal of Quality Assurance in Hospitality \& Tourism, 18(3): 354-378. DOI: 10.1080/1528008X.2016.1230037

Ali, F., Rasoolimanesh, S. M., Sarstedt, M., Ringle, C. M. and Ryu, K. (2018). An Assessment of The Use of Partial Least Squares Structural Equation Modeling (PLS-SEM) In Hospitality Research. International Journal of Contemporary Hospitality Management, 30(1): 514-538.

Altuntuğ, N. (2012). Kuşaktan Kuşağa Tüketim Olgusu ve Geleceğin Tüketici Profili. Organizasyon ve Yönetim Bilimleri Dergisi, 4(1): 203-212.

Arlanda, R. and Suroso, A. (2018). The Influence of Food \& Beverage Quality, Service Quality, Place, and Perceived Price to Customer Satisfaction and Repurchase Intention. Journal of Research in Management, 1(1): 28-37. 
Baron, R. M. and Kenny, D.A. (1986). The Moderator-Mediator Variable Distinction in Social Psychology Research: Conceptual, Strategic and Statistical Considerations. Journal of Personality and Social Psychology, 51(6): 1173-1182.

Bassiouni, D. H. and Hackley, C. (2014). Generation Z' Children's Adaptation to Digital Consumer Culture: A Critical Literature Review. Journal of Customer Behaviour,13(2): 113-133.

Bayındır, B. ve Yüncü, H.R. (2020). Yaşam Tarzının Kahve Dükkânlarını Tercih Etme Niyeti Üzerine Etkisinin İncelenmesi. Türk Turizm Araştırmaları Dergisi, 4(4): 3137-3151. DOI: 10.26677/TR1010.2020.555

Bengül, S. ve Güven, Ö. (2019). Yiyecek İçecek İşletmelerinde Fiziksel Ortam Kalitesi, Yiyecek Kalitesi ve Servis Kalitesinin Algılanan Değer, Müşteri Memnuniyeti ve Müşteri Bağlılığ1 Üzerindeki Etkisi. Balıkesir Üniversitesi Sosyal Bilimler Enstitüsü Dergisi, 22(42): 375-406.

Bezirgan, M., İlban, M.O. ve Deniz, O. (2019). Z Kuşağı Tüketicilerde Marka Güveni ile Marka Memnuniyetinin Marka Sadakatine Etkisi: Eskişehir Starbucks Örneği, 20. Ulusal Turizm Kongresi, Anadolu Üniversitesi 16-19 Ekim 2019. Eskişehir. ss. 742-746.

Bhakar, S., Agrawal, A. K., Suthar, B. K., Verma, S., Verma, A., Singhal, K., and Singh, P. (2013). Impact of Service Quality, Physical Environment, Employee Behavior on Consumer Perception. Prestige International Journal of Management \& IT-Sanchayan, 2(2): 117-133.

Brady, M. K. and Cronin Jr, J. J. (2001). Some New Thoughts on Conceptualizing Perceived Service Quality: A Hierarchical Approach. Journal of Marketing, 65(3): 34-49.

Chang, K. (2000). The Impact of Perceived Physical Environments on Customers' Satisfaction and Return Intentions. Journal of Professional Services Marketing, 21(2): 75-85.

Chebat, J. C. and Michon, R. (2003). Impact of Ambient Odors on Mall Shoppers' Emotions, Cognition, and Spending: A Test of Competitive Causal Theories. Journal of Business Research, 56(7): 529-539.

Chen, P. and Hu, H. (2010). How Determinant Attributes of Service Quality Influence CustomerPerceived Value: An Empirical Investigation of The Australian Coffee Outlet Industry. International Journal of Contemporary Hospitality Management, 22(4): 535-551.

Choi, B. J. and Kim, H. S. (2013). The Impact of Outcome Quality, Interaction Quality, and Peerto-Peer Quality on Customer Satisfaction with a Hospital Service. Managing Service Quality, 23(3): 188-204.

Cohen, J. (1988). Statistical Power Analysis for the Behavioral Sciences. (2nd Ed.). Hillsdale, NJ: Lawrence Erlbaum Associates Publishers.

Doğan, D. (2018). SmartPLS ile Veri Analizi, US: Charleston SC.

Erden Ayhün, S. (2013). Kuşaklar Arasındaki Farklılıklar ve Örgütsel Yansımaları. Ekonomi ve Yönetim Araştırmaları Dergisi, 2(1): 93-112.

Fornell, C. and Larcker, D.F. (1981), Evaluating Structural Equation Models with Unobservable Variables and Measurement Error, Journal of Marketing Research, 18(1): 39-50.

Güzel, Ö. (2018). Kuşakların Değişen Ruhu: Milenyum (Y) Kuşağı Turistlerini Anlamak ve Çözümlemek, (Editörler) Özkoç, H.H. ve Bayrakdaroğlu, F.: Kuşak Kavramına Disiplinler Arası Bakış 2 içinde (ss. 1-21) Ankara: Nobel Nobel Yayınevi.

Hair Jr, J. F., Hult, G. T. M., Ringle, C. M. and Sarstedt, M. (2016). A Primer on Partial Least Squares Structural Equation Modeling (PLS-SEM), Los Angeles: Sage Publications. 
Han, H. and Ryu, K. (2009). The Roles of The Physical Environment, Price Perception, and Customer Satisfaction in Determining Customer Loyalty in The Restaurant Industry. Journal of Hospitality \& Tourism Research, 33(4): 487-510. doi:10.1177/1096348009344212

Hellier, P.K., Geursen, G.M., Carr, R.A. and Rickard, J.A. (2003). Customer Repurchase Intention: A General Structural Equation Model. European Journal of Marketing, 37(11/12): 1762-1800.

Henseler, J., Ringle, C.M. and Sarstedt, M. (2015). A New Criterion for Assessing Discriminant Validity in Varience-Based Structural Equation Modelling, Journal of the academy of marketing science, 43(1): 115-135.

Hidayat, D., Bismo, A. and Basri, A. R. (2020). The Effect of Food Quality and Service Quality Towards Customer Satisfaction and Repurchase Intention (Case Study of Hot Plate Restaurants). Manajemen Bisnis, 10(1): 1-9.

Huang, H. C., Chang, Y. T., Yeh, C. Y., and Liao, C. W. (2014). Promote The Price Promotion: The Effects of Price Promotions on Customer Evaluations in Coffee Chain Stores. International Journal of Contemporary Hospitality Management, 26(7): 1065-1082.

Hwang, J. and Ok, C. (2013). The Antecedents and Consequence of Consumer Attitudes Toward Restaurant Brands: A Comparative Study Between Casual and Fine Dining Restaurants. International Journal of Hospitality Management, 32: 121-131.

Ioannou, M. and Melanthiou, Y. (2015). The Effect of Interaction Quality on Trust, Loyalty and Cross-Selling, International Economics Letters, 4(1): 1-14.

Kement, Ü. (2019). Üçüncü Nesil Kahve Sunan İşletmelerde Hizmet Kalitesi, Müşteri Tatmini ve Davranışsal Niyet İncelemesi; Algılanan Fiyatın Düzenleyicilik Rolü, Journal of Tourism and Gastronomy Studies, 7(2): 1252-1270.

Khan, M. A. (2010). An Empirical Assessment of Service Quality of Cellular Mobile Telephone Operators in Pakistan. Asian Social Science, 6(10): 164-177.

Kılıç, B. ve Kurnaz, A. (2012). Yiyecek İçecek İşletmelerinde Hizmet Kalitesinin DINESERV Modeli ile Ölçümü. Finans Politik ve Ekonomik Yorumlar, 49(564): 87-104.

Kim, M., Vogt, C. A. and Knutson, B. J. (2015). Relationships Among Customer Satisfaction, Delight, and Loyalty in The Hospitality Industry. Journal of Hospitality \& Tourism Research, 39(2): 170-197.

Kim, S. H., Kim, M. and Holland, S. (2018). How Customer Personality Traits Influence Brand Loyalty in The Coffee Shop Industry: The Moderating Role of Business Types. International journal of hospitality $\mathcal{E}$ tourism administration, 19(3): 311-335.

Kim, W. G. and Moon, Y. J. (2009). Customers' Cognitive, Emotional, and Actionable Response to The Servicescape: A Test of The Moderating Effect of The Restaurant Type. International journal of hospitality management, 28(1): 144-156.

Kumar, S. and Bhatnagar, D. (2017). Factors Affecting Customer Satisfaction of Food and Beverage Outlets-A Study of Food and Beverage Outlets Between Amritsar and Jalandhar. IOSR Journal of Humanities and Social Science, 22(9): 65-71.

Kuo, Y. F., Wu, C. M. and Deng, W. J. (2009). The Relationships Among Service Quality, Perceived Value, Customer Satisfaction, and Post-Purchase Intention in Mobile Value-Added Services. Computers in Human Behavior, 25(4): 887-896.

Lee, W. S., Moon, J. and Song, M. (2018). Attributes of The Coffee Shop Business Related to Customer Satisfaction. Journal of Foodservice Business Research, 21(6): 628-641. 
Lestari, V. T. and Ellyawati, J. (2019). Effect of E-Service Quality on Repurchase Intention: Testing the Role of E-Satisfaction as Mediator Variable. International Journal of Innovative Technology and Exploring Engineering, 8(7): 158-162.

Levickaite, R. (2010). Generations X, Y, Z: How Social Networks Form the Concept of the World Without Borders (The Case of Lithuania). LIMES: Cultural Regionalistics, 3(2): 170-183.

Maroco, A. L. and Maroco, J. (2013). Service Quality, Customer Satisfaction and Loyalty. European Journal of Tourism, Hospitality and Recreation, 4(3): 119-145.

Mensah, I. and Dei Mensah, R. (2018). Effects of Service Quality and Customer Satisfaction on Repurchase Intention in Restaurants on University of Cape Coast Campus. Journal of Tourism, Heritage \& Services Marketing, 4(1): 27-36.

Namin, A. (2017). Revisiting Customers' Perception of Service Quality in Fast Food Restaurants. Journal of Retailing and Consumer Services, 34: 70-81.

Nomnga, V. J. and Mhlanga, O. (2015). An Assessment of Customer Satisfaction and Service Quality: The Case of Hotels in East London, South Africa. African Journal of Hospitality, Tourism and Leisure, 4(2): 1-13.

Nguyen, Q. (2020). Engaging Generation Z Customers in Coffee House Industry: Comparative Analysis of The Vietnamese and Finnish Markets, Unpublished Thesis, Centria University of Applied Sciences, Finland.

Parasuraman, A., Zeithaml, V.A. and Berry L.L. (1985). A Conceptual Model of Service Quality and its Implications for Future Research, Journal of Marketing, 49: 41-50.

Phuong, N. N. D. and Dai Trang, T. T. (2018). Repurchase Intention: The Effect of Service Quality, System Quality, Information Quality, and Customer Satisfaction as Mediating Role: A PLS Approach of M-Commerce Ride Hailing Service in Vietnam. Marketing and Branding Research, 5: 78-91.

Priporas, C. V., Stylos, N. and Fotiadis, A. K. (2017). Generation Z Consumers' Expectations of Interactions in Smart Retailing: A Future Agenda. Computers in Human Behavior, 77: 374-381.

Qin, H. and Prybutok, V. R. (2009). Service Quality, Customer Satisfaction, and Behavioral Intentions in Fast-food Restaurants. International Journal of Quality and Service Sciences, 1(1): 78-95.

Quintao, Z. and Prasonnguskarn, K. (2017). A Relationship Study of Price Promotion, Customer Quality Evaluation, Customer Satisfaction and Repurchase Intention: A Case Study of Starbucks in Thailand. International Journal of Management and Applied Science, 3(9): 29-32.

Ryu, K. and Han, H. (2010). Influence of the Quality of Food, Service, and Physical Environment on Customer Satisfaction and Behavioral Intention in Quick-Casual Restaurants: Moderating Role of Perceived Price. Journal of Hospitality \& Tourism Research, 34(3): 310-329.

Ryu, K. and Han, H. (2011). The Influence of Physical Environments on Disconfirmation, Customer Satisfaction, and Customer Loyalty for First-Time and Repeat Customers in Upscale Restaurants. International Journal of Hospitality Management, 30(3): 599-611.

Sarstedt, M., Ringle, C.M. and Hair, J.F. (2017), Partial Least Squares Structural Equation Modelling, In C. Homburg, M.Klarmann, A.Vomberg (Eds.), Handbook of Market Research, Heidelberg: Springer.

Sasongko, F., Darussalam, R., Putra, S.H., Sofian, S. and Mustaqim, T. (2020). Attributes of Coffee Shop as Antecedent of Customer Satisfaction. Journal of Business and Behavioral Entrepreneurship, 4(2): 106-124. https://doi.org/10.21009/JOBBE.004.2.09. 
Soebandhi, S., Wahid, A. and Darmawanti, I. (2020). Service Quality and Store Atmosphere on Customer Satisfaction and Repurchase Intention. BISMA (Bisnis dan Manajemen), 13(1): 26-36.

Taylor, S. A. and Baker, T. L. (1994). An Assessment of the Relationship Between Service Quality and Customer Satisfaction in the Formation of Consumers' Purchase Intentions. Journal of Retailing, 70(2): 163-178.

Vanniarajan T. and Gurunathan, P. (2009). Evaluation of Linkage Between Service Quality, Customer Satisfaction and Repurchase Intentions: An Application of SEM, Asia Pacific Business Review, 5(4): 108-118.

Wall, E. A. and Berry, L. L. (2007). The Combined Effects of the Physical Environment and Employee Behavior on Customer Perception of Restaurant Service Quality. Cornell Hotel and Restaurant Administration Quarterly, 48(1): 59-69.

Wiranto, I. I. J., and Husin, H. A. (2016). Relationship Between Customer Satisfaction and Repurchase Intention on McDonald's Kuala Lumpur. BERJAYA Journal of Services \& Management, 6: 70-79.

Yıldız, E. (2020). SmartPLS ile Yapısal Eşitlik Modellemesi Rekleftif ve Formatif Yapılar. Ankara: Seçkin Yayıncilik.

Zengin, E. ve Erdal, A. (2000). Hizmet Sektöründe Toplam Kalite Yönetimi, Journal of Qafqaz University, 3(1): 43-56. 